\title{
Tarmflora påvirker metabolismen
}

\section{Tarmfloraen endrer seg gjennom graviditeten. Mus med tarmflora fra kvinner i siste trimester legger mer på seg}

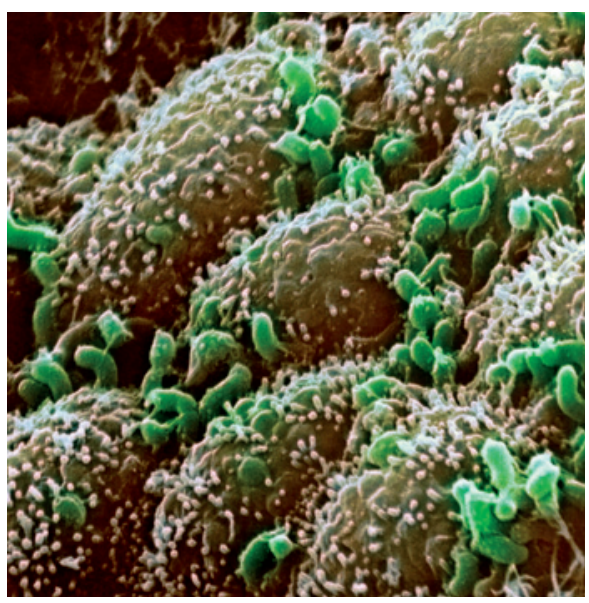

Illustrasjonsfoto Science Photo Library/NTB scanpix
Under graviditeten endres kvinnens metabolisme og immunrespons. Nivået av sirkulerende inflammasjonsfaktorer øker og insulinfølsomheten faller. For å se om disse endringene har sammenheng med bakteriesammensetningen i tarmen, kartla forskere avføringsprøver fra 91 kvinner i første og tredje trimester. De fant at sammensetningen av tarmfloraen endret seg i løpet av svangerskapet, $o g$ at nivået av inflammasjonssignaler i avføringen økte fra første til tredje trimester (1). Dette sammenfalt med økende andel inflammasjonsfremmende tarmbakterier.

Forskerne ga tarmflora fra kvinner i første og tredje trimester til mus uten egen bakterieflora (kimfrie mus). Mus som fikk tarmflora fra kvinner i tredje trimester, hadde høyere nivåer av inflammasjonsmarkører i avføringen. Disse musene la også mer på seg og responderte dårligere på glukosebelastning enn mus som fikk bakterieflora fra kvinner i første trimester.

- Denne studien viser at tarmfloraen endrer seg i løpet av svangerskapet, på en måte som kan påvirke vertens metabolske status i retning av økt fettlagring og nedsatt insulinfølsomhet, sier Jørgen Valeur, lege og forsker ved Klinikk for medisin, ved Lovisenberg Diakonale Sykehus. Forandringer i tarmfloraen er tidligere blitt satt i sammenheng med utvikling av fedme og insulinresistens, men under en graviditet kan slike prosesser til en viss grad være gunstige.

- Funnene kan tyde på at menneskets svangerskap er et slags samarbeidsprosjekt mellom vert og mikrober, trolig til nytte for begge parter. Fra et mikrobielt perspektiv betyr en fødsel at det dannes en ny vertskropp som kan koloniseres, sier Valeur.

\section{Kristin Viste}

kristin.viste@legeforeningen.no

Tidsskriftet

\section{Litteratur}

1. Koren O, Goodrich JK, Cullender TC et al. Host remodeling of the gut microbiome and metabolic changes during pregnancy. Cell 2012; 150: 470-80.

\section{Gener, stress og muskelsmerter}

\author{
Noen kan ha en medfødt genetisk disposisjon for å utvikle muskel- \\ smerter under langvarig stress.
}

Langvarige, lokaliserte ryggsmerter kan ofte utvikle seg til omfattende muskelsmerter. Det har vært kjent lenge at pasienter med generaliserte muskelplager har mer psykiske plager enn de med lokaliserte. I noen få og mindre studier har man funnet varierende grad av assosiasjon mellom enkeltnukleotidpolymorfismer (SNP) i genene for katekolamin-O-metyltransferase (COMT), beta2-adrenerg reseptor (ADRB2) og kroniske muskel- og skjelettplager.

Vi har nylig gjennomførte en populasjonsstudie for å finne en mulig sammenheng mellom medfødt variasjon (polymorfisme) av adrenerge kontrollgener som er involvert i stressreaksjoner, og kronisk muskelsmerte i nakke og rygg hos ungdommer i Perth, Australia (1).

Ungdom i 17-årsalderen fylte ut et spørreskjema som inneholdt opplysninger om psykososiale forhold og opplevd smerte. Blodprøver ble tatt og analysert på DNA og genotyping ble foretatt. Genotypedata ble oppnådd fra 14 enkeltnukleotidpolymorfismer $\mathrm{i}$ to kandidatgener, beta-2- adrenerg reseptor (ADRB2) og katekolamin-O-metyl- transferase (COMT). Haplotyper ble også rekonstruert.

Kjønn og dårlig mental helse var assosiert med kroniske nakke- og ryggsmerter og generaliserte muskelplager. Av de 14 enkeltnukleotidpolymorfismene som ble undersøkt, var en ADRB2-recessiv modell klart assosiert med kroniske nakke- og ryggsmerter (oddsratio 2,49). Dataene indikerer at genetiske varianter i ADRB2 er involvert i kroniske muskel- og skjelettplager hos ungdom. Våre resultater og en ny tilsvarende britisk studie med voksne indikerer at det kan foreligge genetiske varianter i ADRB2-genet lokalisert i muskulatur hos personer som utvikler muskel- og skjelettsmerter ved langvarig stress.

\section{Jan Sture Skouen}

jan.skouen@helse-bergen.no

Avdeling for fysikalsk medisin og rehabilitering Haukeland universitetssykehus

\footnotetext{
Litteratur

1. Skouen JS, Smith AJ, Warrington NM et al. Genetic variation in the beta-2 adrenergic receptor is associated with chronic musculoskeletal complaints in adolescents. Eur J Pain 2012; e-publisert 13.3.2012.
}

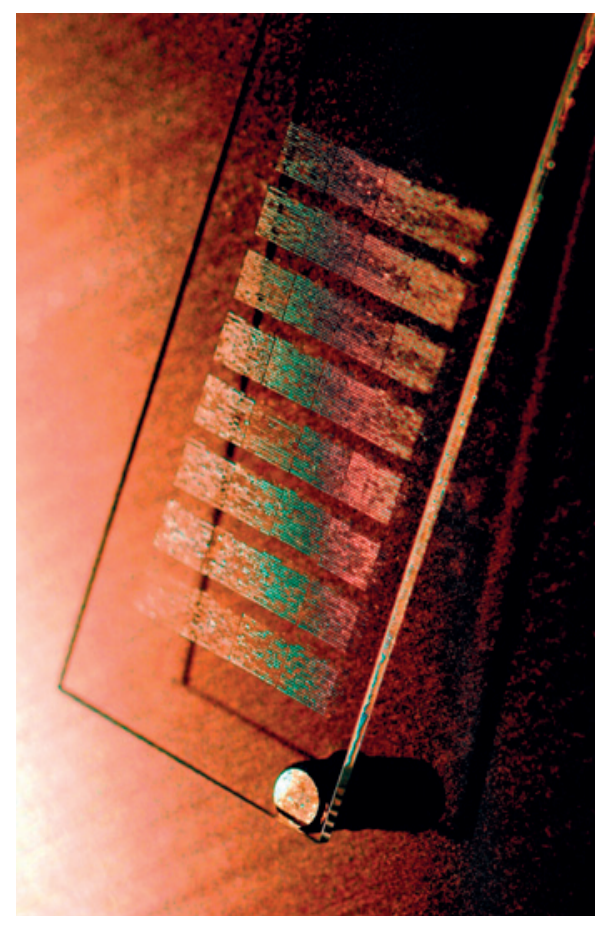

Illustrasjonsfoto Science Photo Library/NTB scanpix 